\title{
Implementasi Analytic Hierarchy Process Sebagai Metode Penilaian Dalam Seleksi Calon Pemain Handball
}

\author{
Muh. Ikhsan Amar ${ }^{1, *}$, Muhammad Hidayat cakrawijaya ${ }^{2}$ \\ ${ }^{1}$ FIKOM, Program Studi Ilmu Komputer, Universitas Megarezky, Makassar, Indonesia \\ ${ }^{2}$ FKIP, Program Studi Pendidikan Jasmani, Universitas Megarezky, Makassar, Indonesia \\ Email: 1,*ikhsan.amar93@gmail.com, ${ }^{2}$ mochcakrapasau@gmail.com \\ Email Penulis Korespondensi: ikhsan.amar93@gmail.com \\ Submitted: 19/12/2021; Accepted: 27/12/2021; Published: 31/12/2021
}

\begin{abstract}
Abstrak-Club olahraga manapun tentu mengharapkan komposisi pemain yang baik serta sesuai dengan standar yang telah ditetapkan. Seperti halnya pada Club Olahraga Handball. Untuk memperoleh pemain tersebut, perlu dilakukan recruitment yang selektif dan komprehensif. Proses recruitment pemain merupakan suatu hal vital karena dapat menentukan kesuksesan dan keberhasilan suatu club olahraga. Prosesi ini bukanlah perkara yang mudah, sebab melibatkan banyak kriteria pemain yang harus dinilai serta mengakumulasi hasil penilaian juga perlu dilakukan dengan suatu metode/algoritma yang objektif. Penelitian ini bertujuan untuk merancang system penilaian calon pemain handball menggunakan metode Analytic Hierarchy Process dan diimplementasikan menjadi perangkat lunak berbasis web. Proses penelitian dan implementasi system menggunakan metode Waterfal yang dikembangkan sesuai kebutuhan dalam penelitian. Hasil dari penelitian ini berupa perangkat lunak berbasis web dan data kriteria serta subkriteria penilaian yang terdiri atas kriteria postur dengan subkriteria tinggi badan dengan bobot eigen 0.07 dan berat badan 0.04, kriteria postur dengan subkriteria situp dengan bobot eigen 0.06 , pushup 0.10 , sprint 0.13 , dan shuttle run 0.14 , dan kriteria teknik dengan subkriteria passing dengan bobot eigen 0.16 , flying shoot 0.14 , dan standing throw shoot dengan bobot eigen 0.15 . Untuk skala penilaian menggunakan skala linguistik yaitu kategori sangat baik dengan bobot eigen 0.55 , baik 0.26 , cukup baik 0.12 , dan kurang baik dengan bobot eigen 0.05 .
\end{abstract}

Kata Kunci: Club Olahraga; Teknik Penilaian; Calon Pemain; AHP; Handball

Abstract-Any sports club would expect a good composition of players and in accordance with the standards that have been set. As in the Handball Sports Club. To obtain these players, it is necessary to carry out a selective and comprehensive recruitment. The process of recruiting players is a vital thing because it can determine the success and success of a sports club. This procession is not an easy matter, because it involves many player criteria that must be assessed and accumulating the results of the assessment also needs to be done with an objective method/algorithm. This study aims to design a scoring system for prospective handball players using the Analytic Hierarchy Process method and implemented into web-based software. The research process and system implementation use the Waterfal method which was developed according to the needs of the research. The results of this study are web-based software and criteria data and assessment sub-criteria consisting of posture criteria with height sub-criteria with eigenweights of 0.07 and body weight of 0.04 , posture criteria with situp sub-criteria with eigenweights of 0.06 , pushups 0.10 , sprints 0.13 , and shuttle run 0.14 , and technical criteria with passing sub-criteria with eigenweight 0.16 , flying shoot 0.14 , and standing throw shoot with eigenweight 0.15 . For the rating scale using a linguistic scale, the category is very good with an eigenweight of 0.55 , good 0.26 , quite good 0.12 , and not good with an eigenweight of 0.05 .

Keywords: Sports Club; Assessment Techniques; Prospective Players; AHP; Handball

\section{PENDAHULUAN}

Permainan handball atau bola tangan merupakan olahraga beregu dan terdiri atas 7 pemain yang menggunakan bola sebagai media permainannya[1]. Permainan ini mirip dengan sepak bola, tapi cara memindahkan bola adalah dengan tangan, bukan kaki. Handball merupakan olahraga yang menggunakan tangan untuk memantulkan, melempar, dan memukul bahkan memasukkan bola kedalam gawang[2].

Permainan bola tangan lebih tepat disebut sebagai permainan kombinasi permainan bola basket dan sepak bola, karena teknik dasarnya menyerupai teknik dasar permainan basket dan lapangan permainannya lebih mirip lapangan sepak bola [3]. Di Indonesi organisasi bola tangan bernama Asosiasi Bola Tangan Indonesia atau disingkat ABTI.

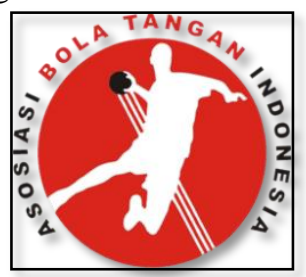

Gambar 1. Logo ABTI [Indosport.com]

Club olahraga manapun tentu sangat mengharapkan pemain sesuai dengan standar atau kriteria yang telah ditetapkan. Seperti cabang olahraga lainnya, pada cabang olahraga bola tangan, pemain merupakan salah satu faktor penting dan berpengaruh sebab pemain yang berkualitas serta memiliki kemampuan yang baik akan medukung penerapan strategi permainan untuk memperoleh kemenangan pada pertandingan. Teknik dasar seorang pemain merupakan unsur dominan dalam menentukan keberhasilan sebuah tim disamping taktik dan strategi yang matang. Kemampuan individu dalam sebuah tim berperan besar bagi tim untuk mendukung berjalannya taktik dan strategi 
secara maksimal. Tanpa adanya dukungan teknik mungkin saja taktik dan strategi sebagus apapun tidak akan berpengaruh[4]. Olehnya itu proses recruitment pemain pada hampir semua cabang olahraga adalah hal yang vital sehingga harus dilakukan secara selektif dan komprehensif.

Analytic Hierarchy Process (AHP) merupakan suatu metode pengambilan keputusan dengan model hirarki fungsional[5]. Dasar berfikir dari model AHP adalah proses pembobotan untuk menyusun peringkat dari setiap alternatif keputusan berdasarkan pada seberapa baik alternatif tersebut memenuhi kriteria pengambil keputusan[6].

Metode AHP dipilih dikarenakan metode ini memiliki stuktur penyelesaian masalah dengan pola hirarki, sehingga permasalahan yang kompleks dan tidak tersruktur dapat diselesaikan dengan membagi permasalahan kedalam bentuk hirarki fungsional yang terorganisir dan terstruktur. Metode AHP telah diterapkan ke berbagia topik permasalahan seperti penetuan lokasi, pembelian property, dan bidang olahraga[5][7][8].

Penelitian tentang metode AHP dan Sistem Pendukung Keputusan (SPK) baik dengan metode AHP maupun metode SPK lainnya telah banyak dilakukan, namum menurut tinjauan yang dilakukan oleh Jufriadif Na'am pada tahun 2017 menunjukkan hasil bahwa penggunaan metode AHP pada SPK mencapai 50 \% jika dibandingkan dengan metode SPK lainnya[9].

Metode AHP banyak digunakan dalam kasus SPK selain karena memiliki pola penyelesaian masalah, juga dikarenakan memiliki keunggulan dalam memberikan perbandingan dan pembobotan antar kriteria dan alternative[7][10]. Berbagai penelitian dengan topik SPK dan metode AHP telah banyak dilakukan, namun sampai pada saat penelitian ini diajukan belum terdapat penelitian tentang SPK pada bidang olahraga bola tangan yang telah di terbitkan di jurnal nasional yang di index oleh google scholar.

Berdasarkan hasil analisis teori serta uraian permasalahan maka penelitian ini bertujuan untuk membangun system penilaian dengan metode AHP untuk mendukung pengambilan keputusan dalam recruitment pemain bola tangan.

\section{METODOLOGI PENELITIAN}

\subsection{Tahapan Penelitian}

Pada penelitian ini digunakan teknik Waterfal yang kemudian dikembangkan dan sesuaikan dengan penelitian yang dilakukan. Pelaksanaan penelitian dilakukan dengan sistematik dan sekuensial yang merupakan model dari metode Waterfall [11][12].

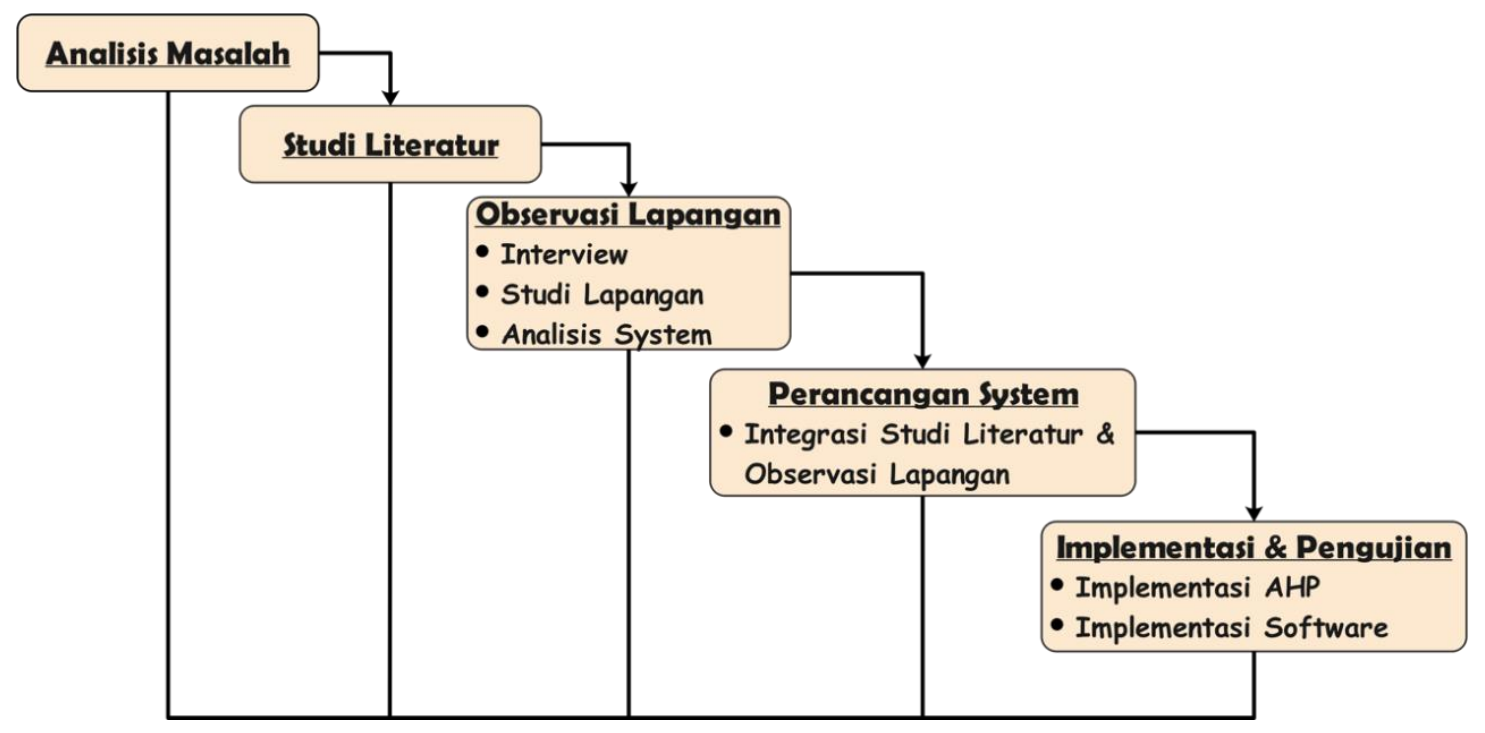

Gambar 2. Tahap Penelitian

a. Analisis Masalah

Pada tahap awal penelitian, dilakukan analisis dan identifikasi terhadap objek permasalahan, yang dalam hal penelitian ini adalah melakukan penilaian terhadap calon atlet pemain bola tangan.

b. Studi Literatur

Setelah analisis dan identifikasi masalah, tahap penelitian selanjutnya adalah mengumpulkan bahan pustaka yang relevan untuk dikaji guna memperoleh landasan dan kerangka teori.

c. Observasi lapangan

Pada tahap observasi, penelitian dilaksanakan dengan interview pengurus/anggota ABTI Provinsi Sulawesi Selatan dan pelatih club bola tangan Universitas Megarezky serta meninjau langsung aktivitas seleksi calon pemain bola tangan Universitas Megarezky Makassar.

d. Perancangan System Penilaian 
Dari hasil observasi lapangan, diperoleh gambaran system serta indikator penilaian pada seleksi calon pemain bola tangan. Selanjutnya dilakukan integrasi hasil observasi lapangan dengan hasil kajian pustaka.

e. Implementasi Metode

System dan indikator penilaian yang diperoleh akan diolah dengan metode AHP, implementasi metode AHP dilakukan mulai dari perbandingan berpasangan antar kriteria sampai uji konsistensi.

f. Pengujian Metode

Hasil pengolahan metode AHP diperoleh nilai bobot untuk masing-masing indikator/kriteria penilaian, bobot tersebut selanjutnya dijadikan landasan dalam penilaian calon pemain bola tangan.

\subsection{Metode AHP}

Algoritma Analytical Hierarchy Process (AHP) dikembangkan awal tahun 1970-an oleh Thomas L. Saaty, seorang ahli matematika dari Universitas Pittsburg[13]. AHP adalah sebuah hierarki fungsional dengan input utamanya persepsi manusia. Dengan hierarki, suatu masalah kompleks dan tidak terstruktur dipecahkan ke dalam kelompokkelompok tersebut diatur menjadi suatu bentuk hierarki. Model AHP memakai persepsi manusia yang dianggap "pakar" sebagai input utamanya. Kriteria "pakar" mengacu pada orang yang mengerti benar permasalahan yang diajukan, merasakan akibat suatu masalah atau punya kepentingan terhadap masalah tersebut[7].

Dasar berfikir dari AHP adalah proses pembobotan untuk menyusun peringkat dari setiap alternatif keputusan berdasarkan pada seberapa baik alternatif tersebut memenuhi kriteria pengambil keputusan. AHP mempunyai kemampuan memecahkan masalah multikriteria berdasarkan perbandingan preferensi elemen hirarki[9].

Menurut Saaty, hirarki didefinisikan sebagai suatu representasi dari sebuah permasalahan yang kompleks dalam suatu struktur multilevel dimana level tertinggi adalah tujuan, yang diikuti level faktor, kriteria, sub kriteria, dan seterusnya ke bawah hingga level terakhir dari alternatif. Dengan hirarki, suatu masalah yang kompleks dapat diuraikan ke dalam kelompok-kelompoknya yang kemudian diatur menjadi suatu bentuk hirarki sehingga permasalahan akan tampak lebih terstruktur dan sistematis. Pada hirarki terendah dilakukan proses evaluasi atas alternatif-alternatif yang merupakan ukuran dari pencapaian tujuan utama[7][9]. Sebagaimana langkah yang dijelaskan oleh Saaty, metode AHP dapat digunakan untuk membantu pengambilan keputusan dengan cara sebagai berikut:

a. Mengidentifikasi Permasalahan dengan menentukan tujuan, kriteria, dan alternatif keputusan.

b. Decomposition

Decomposition merupakan penentuan "pohon hierarki" (hierarchical tree) dengan membagi kriteria dan alternatif kedalam elemen-elemen hirarki. Model hierarchical tree dijabarkan berikut:

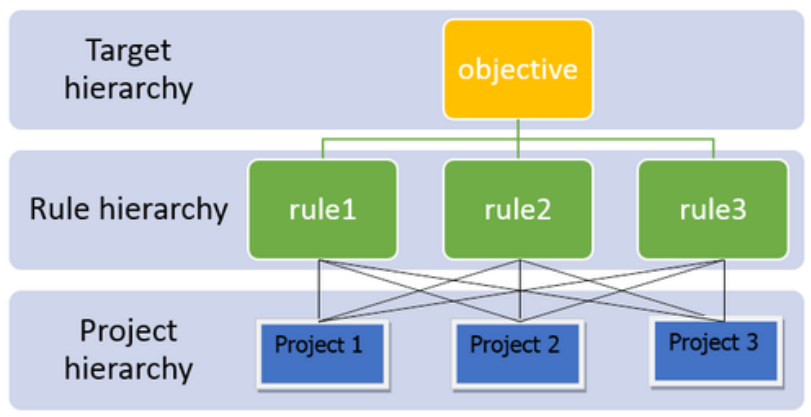

Gambar 3. Model Hirarki AHP.

c. Comparative judgment

Perbandingan berpasangan (pairwise comparison) diimplementasikan kedalam matriks yang diisi dengan bobot yang sesuai dengan tingkat kepentingan atau pengaruhnya. Pertanyaan yang digunakan dalam menyusun skala kepentingan adalah:

1. Elemen mana yang lebih (penting/disukai/berpengaruh/lainnya)

2. Berapa kali lebih (penting/disukai/berpengaruh/lainnya)

\begin{tabular}{l|llll}
$c$ & $A_{1}$ & $A_{2}$ & 000 & $A_{n}$ \\
\hline$A_{1}$ & $A_{11}$ & $A_{12}$ & 000 & $A_{1 n}$ \\
$A_{2}$ & $A_{21}$ & $A_{22}$ & 000 & $A_{2 n}$ \\
000 & 0 & 0 & 000 & $A_{3 n}$ \\
$A_{n}$ & $A_{n 3}$ & $A_{n 2}$ & 000 & $A_{n n}$
\end{tabular}

Gambar 4. Matriks pairwise comparison.

Skala perbandingan yang diberikan mengacu pada tabel 1 berikut. 
Tabel 1. Nilai Skala Perbandingan

\begin{tabular}{ccc}
\hline Prioritas & Definisi Variabel & Skala \\
\hline 1 & Dua elemen mempunyai kepentingan sama & Sama Besar \\
3 & Satu elemen sedikit lebih penting dari yang lain & Sedikit Lebih Besar \\
5 & Satu elemen lebih penting dari yang lain & Lebih Besar \\
7 & Satu elemen sangat lebih penting dari yang lain & Sangat Lebih Besar \\
9 & Satu elemen mutlak lebih penting dari yang lain & Mutlak Lebih Besar \\
$2,4,6,8$ & Diberikan pada nilai antara & \\
\hline
\end{tabular}

d. Synthesis of priority (Menentukan Prioritas)

Prioritas dari kriteria merupakan bobot dari elemen hirarki terhadap tujuan. Mementukan nilai kriteria dan alternatif dari matriks dilakukan dengan nilai eigenvector. Penentuan prioritas dilakukan dengan:

1. Menentukan matriks perbandingan berpasangan.

2. Menentukan eigenvector masing-masing kriteria/alternative

3. Menentukan peringkat kriteria/alternative

4. Menetukan Peringkat alternatif dengan nilai eigenvector.

e. Logical Consistency (Uji Konsistensi)

Matriks yang diperoleh dari hasil perbandingan berpasangan selanjutnya dilakukan uji konsistensi dimana elemen matrik harus mempunyai hubungan kardinal dan ordinal. Hubungan tersebut ditunjukkan berikut ini:

Hubungan kardinal: $A i j$. Ajk $=$ Aik

Hubungan ordinal: $A i>A j>A l>A k$, maka $A i>A k$.

Hubungan tersebut dapat dilihat dengan melihat hubungan preferensi elemen, sebagai contoh, jika durian lebih enak tiga kali dari rambutan dan rambutan lebih enak dua kali dari buah duku maka durian lebih enak lima kali dari duku. Uji konsistensi dilakukan dengan mengikuti langkah-langkah sebagai berikut:

1. Mengalikan matriks sesuai dengan prioritas.

2. Menjumlahkan hasil kali matriks.

3. Hasil penjumlahan dibagi jumlah elemen matriks, maka akan didapatkan $\lambda$ maks.

4. Menentukan indeks Konsistensi $C I$

$$
\mathcal{C} I=\frac{\lambda \max -n}{n-1}
$$

Dimana: $\lambda$ maks $=$ eigenvalue maksimum, $n=$ ukuran matriks.

5. Menentukan Rasio Konsistensi

$$
\mathcal{C R}=\frac{\mathcal{C} i}{\mathcal{R} i}
$$

RI merupakan nilai random indeks, nilai random indeks dapat dilihat pada tabel 2.

Tabel 2. Random Indeks

\begin{tabular}{ccccccccccccccc}
\hline Matriks & $1-2$ & 3 & 4 & 5 & 6 & 7 & 8 & 9 & 10 & 11 & 12 & 13 & 14 & 15 \\
\hline RI & 0.00 & 0.58 & 0.90 & 1.12 & 1.24 & 1.32 & 1.41 & 1.45 & 1.49 & 1.51 & 1.48 & 1.56 & 1.57 & 1.59 \\
\hline
\end{tabular}

Jika $\mathrm{CR}>=0$ maka matriks konsisten, jika $\mathrm{CR}=0,1$ maka matriks cukup konsisten, dan jika $\mathrm{CR}>0,1$ maka matriks sangat tidak konsisten.

\section{HASIL DAN PEMBAHASAN}

Dari studi literature yang dilakukan untuk menentukan indikator/kriteria penilaian bagi calon pemain bola tangan, telah dikumpulkan dan dikaji 5 (lima) literatur yang membahas tentang seleksi pemain bola tangan. kelima literatur tersebut adalah jurnal ilmiah yang dipublikasikan di jurnal nasional antara tahun 2018 sampai tahun 2021.

Dari hasil kajian literature tersebut diperoleh bahwa, pengukuran kondisi dan kesiapan pemain bola tangan dinilai berdasarkan fisik, postur, dan teknik. Pada penelitian [14] tes yang dilakukan dengan menilai teknik passing. Selanjutnya pada penelitian [15] tes dilakukan dengan menguji teknik shoot. Sedangkan pada penelitian yang dilakukan oleh [16][17][18] tes dilakukan adalah menilai kondisi fisik dan postur atlet bola tangan. Olehnya itu pada penelitian ini, penilaian calon pemain dilakukan dengan menggabungkan seluruh substansi penilaian yang digunakan pada penelitian sebelumnya yakni penilaian dengan kriteria postur, fisik, dan teknik. Adapun sub kriteria pada masingmasing kriteria penilaian diperoleh dari hasil observasi lapangan dan interview, adapun sub kriteria penilaian untuk masing-masing kriteria adalah sebagai berikut:

Tabel 3. Kriteria Penilaian

\begin{tabular}{clll}
\hline No. & Kriteria Penilaian & Subkriteria Penilaian & Metode Penilaian \\
\hline 1 & Postur & Tinggi Badan & Pengukuran Tinggi Badan \\
& & Berat Badan & Menimbang Berat Badan \\
\hline
\end{tabular}




\begin{tabular}{clll}
\hline No. & Kriteria Penilaian & Subkriteria Penilaian & Metode Penilaian \\
\hline 2 & Fisik & Otot Perut & Situp \\
& & Otot Lengan dan Bahu & Pushup \\
& & Kecepatan dan Stamina & Sprint 30 M \\
& & Kelincahan & Shuttle Run 30 M \\
\hline 3 & Teknik & Passing & Passing \\
& & Flying Shoot & Flying Shoot \\
& & Standing Throw Shot & Standing Throw Shot \\
\hline
\end{tabular}

Kriteria penilaian pada tabel 3 akan digunakan pada saat tes dan penilaian calon pemain. Nilai/poin yang diperoleh oleh calon pemain berdasarkan hasil penilaian diintegrasikan menjadi skala linguistik seperti yang ditunjukkan pada tabel 4. Selanjutnya, hasil penilaian akan dikonversi kedalam penilaian menggunakan skala perbandingan berpasanganan dengan menggunakan metode AHP.

Tabel 4. Skala Penilaian

\begin{tabular}{ccccc}
\hline Skala Penilaian & 4 & 3 & 2 & 1 \\
\hline Skala Linguistik & Sangat Baik & Baik & Cukup Baik & Kurang Baik \\
\hline
\end{tabular}

a. Integrasi Kriteria Penilaian dan Skala Penilaian

Skala penilaian kriteria postur diperoleh dari observasi lapangan dan interview pengurus/anggota ABTI Provinsi Sulawesi Selatan dan pelatih club bola tangan Universitas Megarezky.

Tabel 5. Bobot Kriteria Penilaian Postur

\begin{tabular}{lll}
\hline Kriteria Penilaian & Satuan Penilaian & Kategori Skala \\
\hline Tinggi Badan & $>170 \mathrm{~cm}$ & Sangat Baik \\
& $160-169 \mathrm{~cm}$ & Baik \\
& $150-159 \mathrm{~cm}$ & Cukup Baik \\
& $<150 \mathrm{~cm}$ & Kurang Baik \\
\hline Berat Badan & $3-0 \mathrm{~kg}$ dari BMI & Sangat Baik \\
& $6-3 \mathrm{~kg}$ dari BMI & Baik \\
& $3-9 \mathrm{~kg}$ dari BMI & Cukup Baik \\
& $>9 \mathrm{~kg}$ dari BMI & Kurang Baik \\
\hline
\end{tabular}

Skala penilaian pada kriteria fisik ditentukan berdasarkan data yang diperoleh dari penelitian yang dilaksanakan oleh [19][20], dimana skala penilaian tersebut dijabarkan berikut ini.

Tabel 6. Bobot Kriteria Penilaian Fisik

\begin{tabular}{lll}
\hline Kriteria Penilaian & Satuan Penilaian & Kategori Skala \\
\hline Sit Up 30 Detik & $>30$ Repetisi & Sangat Baik \\
& $26-30$ Repetisi & Baik \\
& $20-25$ Repetisi & Cukup Baik \\
& $<19$ Repetisi & Kurang Baik \\
\hline Push Up 30 Detik & $>34$ Repetisi & Sangat Baik \\
& $25-33$ Repetisi & Baik \\
& $18-24$ Repetisi & Cukup Baik \\
& $<18$ Repetisi & Kurang Baik \\
\hline Sprint 30 M & $3.58-3.91$ detik & Sangat Baik \\
& $3.92-4.34$ detik & Baik \\
& $4.35-4.72$ detik & Cukup Baik \\
& $>4.72$ detik & Kurang Baik \\
\hline Shuttle Run 30 M & $<12.10$ detik & Sangat Baik \\
& $12.11-13.53$ detik & Baik \\
& $13.54-14.96$ detik & Cukup Baik \\
& $>14.97$ detik & Kurang Baik \\
\hline
\end{tabular}

Skala penilaian kriteria teknik diperoleh dari hasil observasi dan interview pengurus/anggota ABTI Provinsi Sulawesi Selatan dan pelatih club bola tangan Universitas Megarezky. Penilaian teknik menggunakan skala penilaian 1-100 yang diukur dari keakuratan, kekuatan, dan kecepatan passing dan shoot.

Tabel 7. Bobot Kriteria Penilaian Teknik

\begin{tabular}{lll}
\hline Kriteria Penilaian & Satuan Penilaian & Kategori Skala \\
\hline Passing, & $85-100$ poin & Sangat Baik
\end{tabular}


Building of Informatics, Technology and Science (BITS)

Volume 3, No 3, December 2021, Page 260-268

ISSN 2684-8910 (media cetak)

ISSN 2685-3310 (media online)

DOI 10.47065/bits.v3i3.1031

\begin{tabular}{lll}
\hline Kriteria Penilaian & Satuan Penilaian & Kategori Skala \\
\hline Flying Shoot, & $71-84$ poin & Baik \\
Standing Throw & $60-70$ poin & Cukup Baik \\
Shoot & $<60$ poin & Kurang Baik \\
\hline
\end{tabular}

b. Implementasi Motode AHP Terhadap Kriteria

1. Representasi Masalah

Tabel 8. Representasi Masalah

\begin{tabular}{cll}
\hline No. & Cluster & Data \\
\hline 1. & Tujuan & Penilaian Calon Pemain Bola Tangan. \\
\hline 2. & Kriteria & $\begin{array}{l}\text { 1) Postur = Tinggi Badan (TB), Berat Badan (BB) } \\
\text { 2) Fisik = Push Up (PU), Sit Up (SU), Sprint (SP), Shuttle Run (SR) }\end{array}$ \\
\hline 3. & Subkriteria & S) Teknik = Flying Shoot (FS), Standing Trow Shoot (SS), Passing (PS) \\
\hline 4. & Alternative & Calon Pemain 1, Calon Pemain 2, Calon Pemain 3 \\
\hline
\end{tabular}

2. Jaringan Hirarki

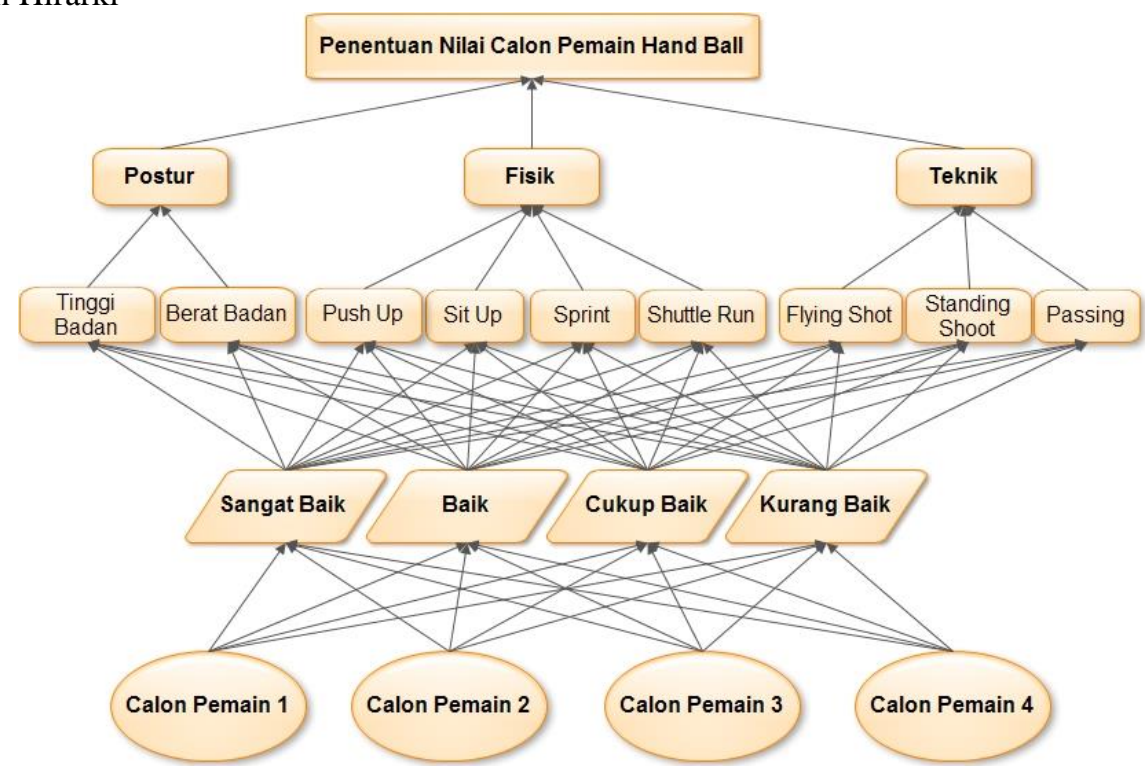

Gambar 5. Jaringan Hirarki Penelitian

3. Perbandingan Berpasangan Kriteria Penilaian

Tabel 9. Matriks Perbandingan Berpasangan Kriteria

\begin{tabular}{c|ccccccccc}
\hline & PS & SS & FS & TB & BB & PU & SU & SP & SR \\
\hline PS & 1 & 3 & 1 & 2 & 5 & 1 & 2 & 1 & 2 \\
SS & 0.33 & 1 & 0.33 & 1 & 1 & 3 & 3 & 3 & 3 \\
FS & 1 & 3 & 1 & 2 & 3 & 1 & 2 & 1 & 1 \\
TB & 0.5 & 1 & 0.5 & 1 & 2 & 0.5 & 1 & 0.5 & 0.33 \\
BB & 0.2 & 1 & 0.33 & 0.5 & 1 & 0.5 & 0.5 & 0.33 & 0.2 \\
PU & 1 & 0.33 & 1 & 2 & 2 & 1 & 3 & 0.33 & 0.33 \\
SU & 0.5 & 0.33 & 0.5 & 1 & 2 & 0.33 & 1 & 0.5 & 0.33 \\
SP & 1 & 0.33 & 1 & 2 & 3 & 3 & 2 & 1 & 1 \\
SR & 0.5 & 0.33 & 1 & 3 & 5 & 3 & 3 & 1 & 1 \\
\hline$\sum$ & $\mathbf{6 . 0 3}$ & $\mathbf{1 0 . 3 2}$ & $\mathbf{6 . 6 6}$ & $\mathbf{1 4 . 5}$ & $\mathbf{2 4}$ & $\mathbf{1 3 . 3 3}$ & $\mathbf{1 7 . 5}$ & $\mathbf{8 . 6 6}$ & $\mathbf{9 . 1 9}$ \\
\hline
\end{tabular}

Matriks pada tabel 9 selanjutnya dijadikan matriks perbandingan berpasangan ternormalisasi.

Tabel 10. Matriks Ternormalisasi Kriteria

\begin{tabular}{c|ccccccccccc}
\hline & PS & SS & FS & TB & BB & PU & SU & SP & SR & $\Sigma$ & Eigen Vektor \\
\hline PS & 0,17 & 0,29 & 0,15 & 0,14 & 0,21 & 0,08 & 0,11 & 0,12 & 0,22 & $\mathbf{1 , 4 8}$ & $\mathbf{0 , 1 6}$ \\
SS & 0,05 & 0,10 & 0,05 & 0,07 & 0,04 & 0,23 & 0,17 & 0,35 & 0,33 & $\mathbf{1 , 3 8}$ & $\mathbf{0 , 1 5}$ \\
FS & 0,17 & 0,29 & 0,15 & 0,14 & 0,13 & 0,08 & 0,11 & 0,12 & 0,11 & $\mathbf{1 , 2 8}$ & $\mathbf{0 , 1 4}$ \\
TB & 0,08 & 0,10 & 0,08 & 0,07 & 0,08 & 0,04 & 0,06 & 0,06 & 0,04 & $\mathbf{0 , 6 0}$ & $\mathbf{0 , 0 7}$ \\
BB & 0,03 & 0,10 & 0,05 & 0,03 & 0,04 & 0,04 & 0,03 & 0,04 & 0,02 & $\mathbf{0 , 3 8}$ & $\mathbf{0 , 0 4}$ \\
PU & 0,17 & 0,03 & 0,15 & 0,14 & 0,08 & 0,08 & 0,17 & 0,04 & 0,04 & $\mathbf{0 , 8 9}$ & $\mathbf{0 , 1 0}$ \\
SU & 0,08 & 0,03 & 0,08 & 0,07 & 0,08 & 0,02 & 0,06 & 0,06 & 0,04 & $\mathbf{0 , 5 2}$ & $\mathbf{0 , 0 6}$ \\
SP & 0,17 & 0,03 & 0,15 & 0,14 & 0,13 & 0,23 & 0,11 & 0,12 & 0,11 & $\mathbf{1 , 1 7}$ & $\mathbf{0 , 1 3}$ \\
SR & 0,08 & 0,03 & 0,15 & 0,21 & 0,21 & 0,23 & 0,17 & 0,12 & 0,11 & $\mathbf{1 , 3 0}$ & $\mathbf{0 , 1 4}$ \\
\hline
\end{tabular}


Matriks ternormalisasi pada tabel 10 selanjutnya dilakukan uji konsistensi.

$$
\begin{aligned}
\lambda_{\text {maks }} & =(10+10,73+9,86+8,66+10,89+7,92+8,03+8,87+9,73) / 9=9,41 \\
C R . & =\frac{9.41-9}{9-1}=0,051 \\
& =0.035
\end{aligned}
$$

Karena $C R<$ dari 0.1 , maka matriks perbandingan berpasangan dinyatakan konsisten.

4. Perbandingan Berpasangan Skala Penilaian

Tabel 11. Matriks Perbandingan Berpasangan Skala Penilaian

\begin{tabular}{c|cccc}
\hline & SB & B & CB & KB \\
\hline SB & 1 & 3 & 5 & 7 \\
B & 0.33 & 1 & 3 & 5 \\
CB & 0.2 & 0.33 & 1 & 3 \\
KB & 0.14 & 0.2 & 0.33 & 1 \\
\hline$\Sigma$ & $\mathbf{1 . 6 7}$ & $\mathbf{4 . 5 3}$ & $\mathbf{9 . 3 3}$ & $\mathbf{1 6}$ \\
\hline
\end{tabular}

Matriks pada tabel 11 selanjutnya dijadikan matriks perbandingan berpasangan ternormalisasi.

Tabel 12. Matriks Ternormalisasi Skala Penilaian

\begin{tabular}{c|cccccc}
\hline & $\boldsymbol{S B}$ & $\boldsymbol{B}$ & $\boldsymbol{C B}$ & $\boldsymbol{K B}$ & $\sum$ & Eigen Vektor \\
\hline $\boldsymbol{S} \boldsymbol{B}$ & 0.59 & 0.66 & 0.53 & 0.43 & $\mathbf{2 . 2 3}$ & $\mathbf{0 . 5 5}$ \\
$\boldsymbol{B}$ & 0.19 & 0.22 & 0.32 & 0.31 & $\mathbf{1 , 0 5}$ & $\mathbf{0 . 2 6}$ \\
$\boldsymbol{C} \boldsymbol{B}$ & 0.12 & 0.07 & 0.10 & 0.18 & $\mathbf{0 , 4 8}$ & $\mathbf{0 . 1 2}$ \\
$\boldsymbol{K} \boldsymbol{B}$ & 0.08 & 0.04 & 0.35 & 0.06 & $\mathbf{0 , 2 2}$ & $\mathbf{0 . 0 5}$ \\
\hline
\end{tabular}

Matriks ternormalisasi pada tabel 12 selanjutnya dilakukan uji konsistensi.

$$
\begin{aligned}
\lambda_{\text {maks }} & =(4.22+4.17+4.03+4.04) / 4=4.11 \\
C I & =\frac{4.11-4}{4-1}=0.036 \\
C R . & =\frac{0.036}{0.90} \\
& =0.04
\end{aligned}
$$

Karena $C R<$ dari 0.1, maka matriks perbandingan berpasangan dinyatakan konsisten

\begin{tabular}{|c|c|c|c|c|c|c|c|c|c|c|c|}
\hline \multirow{2}{*}{$\begin{array}{l}\text { Alter- } \\
\text { native }\end{array}$} & \multicolumn{9}{|c|}{ Kriteria Penilaian } & \multirow{2}{*}{$\Sigma$} & \multirow{2}{*}{$\begin{array}{l}\text { Eigen } \\
\text { Value }\end{array}$} \\
\hline & $\overline{\text { PS }}$ & SS & $\overline{F S}$ & TB & BB & PU & SU & SP & $\begin{array}{l}\text { SR } \\
\end{array}$ & & \\
\hline AL 01 & 0,25 & 0,2875 & 0,0175 & 0,0044 & 0,0003 & 0,0009 & 0,0002 & 0,0018 & 0,0237 & 0,5862 & 0,0651 \\
\hline AL 02 & 0,25 & 0,1359 & 0,0083 & 0,0044 & 0,0012 & 0,0020 & 0,0002 & 0,0018 & 0,0237 & 0,4274 & $\mathbf{0 , 0 4 7 5}$ \\
\hline AL 03 & 0,25 & 0,2875 & 0,0175 & 0,0021 & 0,0012 & 0,0009 & 0,0001 & 0,0018 & 0,0237 & 0,5847 & 0,0650 \\
\hline AL 04 & 0,25 & 0,2875 & 0,0083 & 0,0021 & 0,0003 & 0,0020 & 0,0002 & 0,0084 & 0,0237 & 0,5823 & 0,0647 \\
\hline
\end{tabular}

c. Implementasi Bobot Kriteria Terhadap Alternative

Sebagai studi pengujian terhadap bobot kriteria pada penelitian ini, diambil sampel secara random dari 124 calon pemain yang telah mengikuti test.

Tabel 13. Sampel Penilaian Alternative

\begin{tabular}{cl|ccccccccc}
\hline \multirow{2}{*}{$\begin{array}{c}\text { Kode } \\
\text { Alternativ }\end{array}$} & \multirow{2}{*}{ Nama Calon Pemain } & \multicolumn{8}{|c}{ Kriteria Penilaian } \\
\cline { 2 - 10 } & & PS & SS & FS & TB & BB & PU & SU & SP & SR \\
\hline AL-01 & SAENAL & 4 & 4 & 4 & 4 & 2 & 2 & 2 & 2 & 4 \\
AL-02 & ALFIANDI & 4 & 3 & 3 & 4 & 4 & 3 & 2 & 2 & 4 \\
AL-03 & AZIKIN RAHMAN & 4 & 4 & 4 & 3 & 4 & 2 & 1 & 2 & 4 \\
AL-04 & IRSAN RAHMAN & 4 & 4 & 3 & 3 & 2 & 3 & 2 & 4 & 4 \\
\hline
\end{tabular}

Tabel 14. Matriks Penilaian Alternative

\begin{tabular}{c|ccccccccc}
\hline \multirow{2}{*}{ Alternative } & \multicolumn{8}{c}{ Kriteria Penilaian } \\
\cline { 2 - 10 } & PS & SS & FS & TB & BB & PU & SU & SP & SR \\
\hline AL 01 & 0,088 & 0,083 & 0,077 & 0,039 & 0,005 & 0,012 & 0,007 & 0,016 & 0,077 \\
AL 02 & 0,088 & 0,039 & 0,036 & 0,039 & 0,022 & 0,026 & 0,007 & 0,016 & 0,077 \\
AL 03 & 0,088 & 0,083 & 0,077 & 0,018 & 0,022 & 0,012 & 0,003 & 0,016 & 0,077 \\
AL 04 & 0,088 & 0,083 & 0,036 & 0,018 & 0,005 & 0,026 & 0,007 & 0,072 & 0,077 \\
\hline$\sum$ & $\mathbf{0 , 3 5 2}$ & $\mathbf{0 , 2 8 7}$ & $\mathbf{0 , 2 2 7}$ & $\mathbf{0 , 1 1 3}$ & $\mathbf{0 , 0 5 4}$ & $\mathbf{0 , 0 7 6}$ & $\mathbf{0 , 0 2 5}$ & $\mathbf{0 , 1 1 8}$ & $\mathbf{0 , 3 0 8}$ \\
\hline
\end{tabular}

Tabel 15. Matriks Ternormalisasi 
Building of Informatics, Technology and Science (BITS)

Volume 3, No 3, December 2021, Page 260-268

ISSN 2684-8910 (media cetak)

ISSN 2685-3310 (media online)

DOI 10.47065/bits.v3i3.1031

Dari matriks diatas diperoleh data bahwa sampel dengan kode AL 01 atau Saenal memperoleh nilai vaktor yang paling besar yakni 0,0651 .

d. Implementasi Metode Kesystem Komputer

Hasil penelitian dan rancangan system dengan metode AHP selanjutnya di implementasikan menjadi perangkat lunak berbasis web agar penggunaan metode AHP pada seleksi pemain bola tangan menjadi lebih mudah. Adapun gambaran hasil implementasi tersebut diuraikan berikut ini.

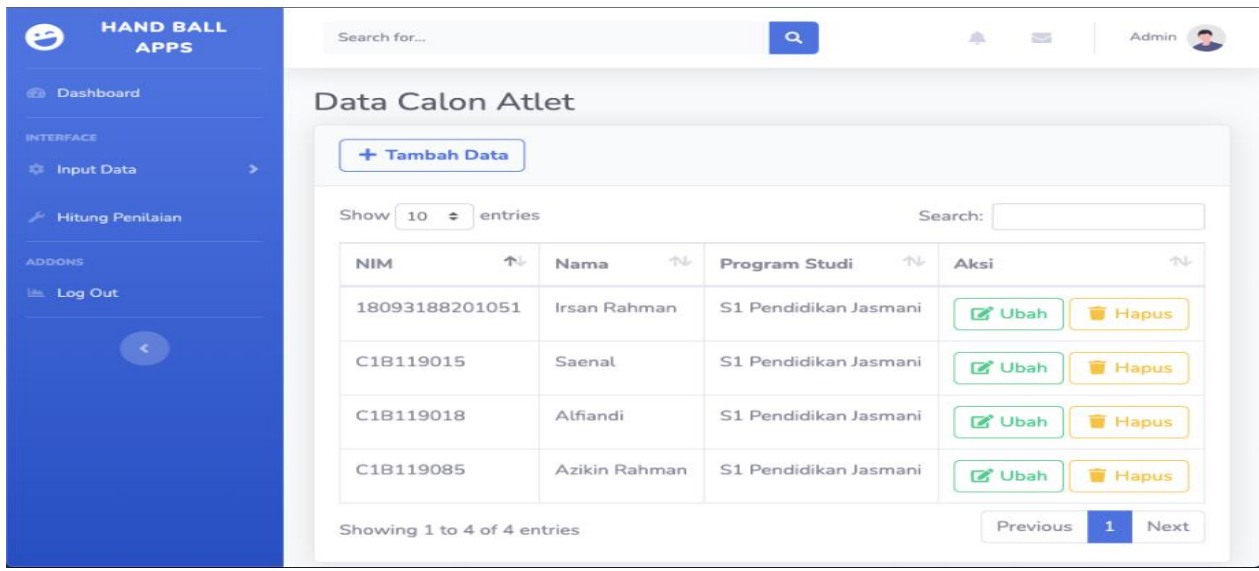

Gambar 6. Halaman Input Data Calon Pemain
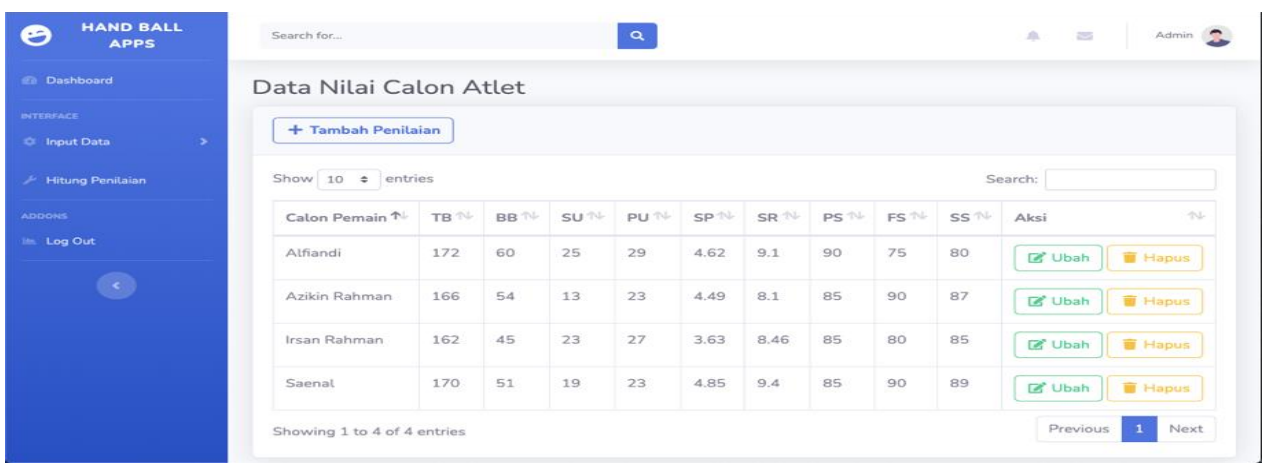

Gambar 7. Halaman Data Nilai Calon Pemain
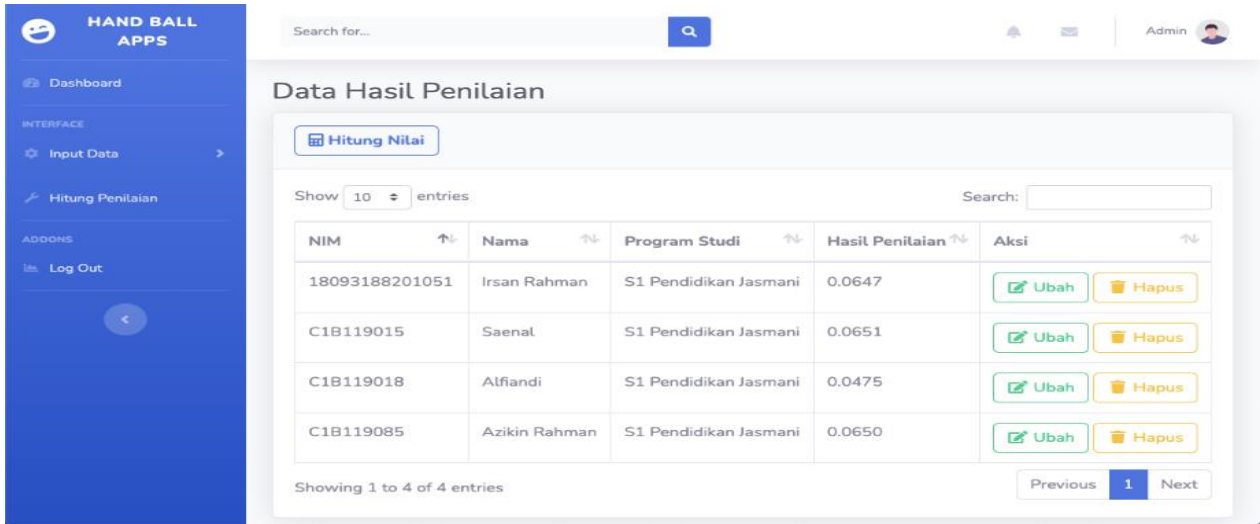

Gambar 8. Halaman Hasil Penilaian Calon Pemain

\section{KESIMPULAN}

Hasil penelitian ini berupa metode penilaian dan perangkat lunak berbasis web yang dapat dijadikan sebagai instrumen dalam seleksi penilaian calon pemain bola tangan, baik pada club bola tangan Universitas Megarezky maupun club bola tangan lainnya, dari hasil penelitian ini juga diperoleh data kriteria dan subkriteria penilaian yang terdiri atas kriteria postur dengan subkriteria tinggi badan dengan bobot eigen 0.07 dan berat badan 0.04 , kriteria postur dengan subkriteria situp dengan bobot eigen 0.06 , pushup 0.10 , sprint 0.13 , dan shuttle run 0.14 , dan kriteria teknik dengan subkriteria passing dengan bobot eigen 0.16 , flying shoot 0.14 , dan standing throw shoot dengan bobot eigen 0.15 . Untuk skala penilaian menggunakan skala linguistik yaitu kategori sangat baik dengan bobot eigen 0.55 , baik 0.26 , cukup baik 0.12 , dan kurang baik dengan bobot eigen 0.05 . 


\section{REFERENCES}

[1] D. R. Budi, R. Hidayat, and A. R. Febriani, "The Application of Tactical Approaches in Learning Handballs," JUARA: Jurnal Olahraga, vol. 4, no. 2, Art. no. 2, Jul. 2019, doi: 10.33222/juara.v4i2.534.

[2] B. Hermansah, "PENGARUH PEMBELAJARAN BOLA TANGAN TERHADAP KEMAMPUAN INTERAKSI SOSIAL MAHASISWA," Wahana Didaktika: Jurnal Ilmu Kependidikan, vol. 16, no. 3, Art. no. 3, Sep. 2018, doi: 10.31851/wahanadidaktika.v16i3.2170.

[3] A. Sumarsono, A. Anisah, and I. Iswahyuni, "Media interaktif sebagai optimalisasi pemahaman materi permainan bola tangan," Jurnal Pendidikan Jasmani Indonesia, vol. 15, no. 1, Art. no. 1, Jun. 2019, doi: 10.21831/jpji.v15i1.24051.

[4] E. Susanto, "Pengembangan tes keterampilan dasar olahraga bola tangan bagi mahasiswa," Jurnal Penelitian dan Evaluasi Pendidikan, vol. 21, no. 1, Art. no. 1, Jun. 2017, doi: 10.21831/pep.v21i1.15784.

[5] A. Asrianda, R. K. Dinata, and R. Hidayat, "SISTEM PENDUKUNG KEPUTUSAN SELEKSI PEMAIN BOLA MENGGUNAKAN METODE ANALYTICAL HIERARCHY PROCESS (AHP)," TECHSI - Jurnal Teknik Informatika, vol. 11, no. 2, Art. no. 2, Jul. 2019, doi: 10.29103/techsi.v11i2.1522.

[6] M. L. C. Buono and A. Latif, "IMPLEMENTASI SISTEM PENDUKUNG KEPUTUSAN MENGGUNAKAN METODE ANALYTIC HIERARCHY PROCESS UNTUK SELEKSI PEMAIN FUTSAL," MUSTEK ANIM HA, vol. 8, no. 03, pp. 169-174, 2019, doi: 10.35724/mustek.v8i03.2709.

[7] G. S. Mahendra and I. P. Y. Indrawan, "METODE AHP-TOPSIS PADA SISTEM PENDUKUNG KEPUTUSAN PENENTUAN PENEMPATAN AUTOMATED TELLER MACHINE," JST (Jurnal Sains dan Teknologi), vol. 9, no. 2, Art. no. 2, Sep. 2020, doi: 10.23887/jst-undiksha.v9i2.24592.

[8] I. Mahendra and P. K. Putri, "IMPLEMENTASI METODE ANALYTICAL HIERARCHY PROCESS (AHP) DALAM SISTEM PENDUKUNG KEPUTUSAN PEMBELIAN RUMAH DI KOTA TANGERANG,” Jurnal Teknoinfo, vol. 13, no. 1, Art. no. 1, Jan. 2019, doi: 10.33365/jti.v13i1.238.

[9] J. Na'am, "Sebuah Tinjauan Penggunaan Metode Analytic Hierarchy Process (AHP) dalam Sistem Penunjang Keputusan (SPK) pada Jurnal Berbahasa Indonesia," Jurnal Ilmiah Media Sisfo, vol. 11, no. 2, Art. no. 2, Oct. 2017.

[10] E. Yunianto and A. P. Wibowo, "IMPLEMENTASI METODE AHP DAN MOORA UNTUK PEMERINGKATAN EMARKETPLACE INDONESIA TAHUN 2020 KUARTAL KEDUA,” Jurnal INSTEK (Informatika Sains dan Teknologi), vol. 6, no. 1, Art. no. 1, Jan. 2021, doi: 10.24252/instek.v6i1.18764.

[11] M. I. Amar, "Sistem Penilaian Kinerja Aparat Pemerintah Desa Dengan Metode Profile Matching," Jurnal Ilmiah Ilmu Komputer Fakultas Ilmu Komputer Universitas Al Asyariah Mandar, vol. 6, no. 1, Art. no. 1, Apr. 2020, doi: 10.35329/jiik.v6i1.126.

[12] I. Sommerville, Software Engineering, 10 edition. Boston: Pearson, 2015.

[13] G. S. Mahendra and K. Y. E. Aryanto, "SPK Penentuan Lokasi ATM Menggunakan Metode AHP dan SAW," Jurnal Nasional Teknologi dan Sistem Informasi, vol. 5, no. 1, Art. no. 1, Apr. 2019, doi: 10.25077/TEKNOSI.v5i1.2019.49-56.

[14] B. Hermansah, "MODIFIKASI PERMAINAN BOLA TANGAN TERHADAP HASIL BELAJAR PASSING DALAM PEMBELAJARAN BOLA TANGAN MAHASISWA," Wahana Didaktika : Jurnal Ilmu Kependidikan, vol. 16, no. 1, Art. no. 1, Jan. 2018, doi: 10.31851/wahanadidaktika.v16i1.1924.

[15] W. Susanti, A. Triansyah, and M. Haetami, "PELUANG GOAL SHOOTING TEKNIK FLYING SHOT DAN STANDING THROW SHOT PADA PERMAINAN BOLA TANGAN," Jurnal Pendidikan dan Pembelajaran Khatulistiwa, vol. 9, no. 1, Art. no. 1, Jan. 2020.

[16] M. Firdaus, M. A. Zawawi, and K. Dwijayanti, "Menghadapi Pekan Olahraga Nasional tahun 2020: sejauh mana profil kondisi fisik atlet bola tangan Provinsi Jawa Tengah," Jurnal SPORTIF : Jurnal Penelitian Pembelajaran, vol. 6, no. 3, Art. no. 3, Dec. 2020, doi: 10.29407/js_unpgri.v6i3.15215.

[17] D. Setiawan, "PERBANDINGAN KOMPONEN KONDISI FISIK ATLET BOLATANGAN KABUPATEN LAMONGAN DAN KABUPATEN GRESIK,” Jurnal Prestasi Olahraga, vol. 4, no. 4, pp. 146-157, Apr. 2021.

[18] R. Y. W. Priantoko and G. Siantoro, "PROFIL KONDISI FISIK ATLET PUTRI PUSLATDA BOLATANGAN JAWA TIMUR PASCA TRAINING FROM HOME TAHUN 2020,” Jurnal Prestasi Olahraga, vol. 4, no. 7, pp. 60-70, Jun. 2021.

[19] E. kamanita br Meliala, "Analisis Kondisi Fisik Atlet Putra Floorball Universitas Negeri Surabaya," JOSSAE (Journal of Sport Science and Education), vol. 3, no. 2, Art. no. 2, 2018, doi: 10.26740/jossae.v3n2.p81-93.

[20] A. P. Ahmad Muchlisin Natas Pasaribu, "Tes dan Pengukuran Olahraga," vol. 1, A. R. Abdul Rahman, Ed. Yayasan Pendidikan dan Sosial: YPSIM, 2020, pp. 1-51. [Online]. Available: http://repository.ubharajaya.ac.id/3283/ 